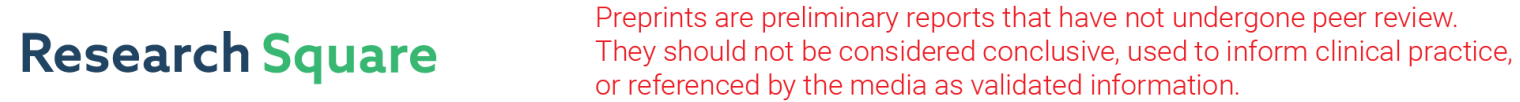 \\ The Disabled Wage Gap between Social Enterprises and Capitalist Enterprises
}

\section{María José Calderón-Milán}

University of Castilla-La Mancha: Universidad de Castilla-La Mancha

\section{Beatriz Calderón-Milán}

University of Castilla-La Mancha: Universidad de Castilla-La Mancha

\section{Virginia Barba-Sanchez ( $\sim$ virginia.barba@uclm.es)}

University of Castilla-La Mancha: Universidad de Castilla-La Mancha https://orcid.org/0000-00030149-0569

\section{Research}

Keywords: Disability equality, Disables people, Social enterprise, Wage gap.

Posted Date: June 14th, 2021

DOl: https://doi.org/10.21203/rs.3.rs-553979/v1

License: (9) This work is licensed under a Creative Commons Attribution 4.0 International License. Read Full License 


\title{
The Disabled Wage Gap between Social Enterprises and Capitalist
}

\section{Enterprises}

\author{
María José Calderón-Milán ${ }^{\mathrm{a}}$, Beatriz Calderón-Milán ${ }^{\mathrm{b}}$, and Virginia Barba-Sánchez ${ }^{\mathrm{c}}$ \\ ${ }^{a}$ Department of Applied Economy, Faculty of Economics and Business Administration, University of Castilla-La \\ Mancha, Avenida de España s/n, 02071 Albacete, Spain. \\ ${ }^{b}$ Department of Spanish and International Economics, Faculty of Economics and Business Administration, \\ University of Castilla-La Mancha, Albacete, Paseo de los Estudiantes, s/n, 02071 Albacete, Spain. \\ ${ }^{c}$ Department of Business Administration, ESII, University of Castilla-La Mancha, Albacete, Paseo de los \\ Estudiantes, s/n, 02071 Albacete, Spain.
}

\begin{abstract}
Background: In recent years, the disabled wage gap between persons with disabilities (PwD) and those without disabilities (PwoD) has widened considerably. However, one of the prime reasons for creating social enterprise is that they include in their goals employ and include vulnerable groups, but such firms are in favor of $\mathrm{PwD}$ in relation to wage or not? The main aim of this article is to analyze whether wage discrimination exists between PwD employed by social enterprises (SE) and those employed by capitalist enterprises (CE).
\end{abstract}

Methods: We used microdata from the Continuous Sample of Work Lives (CSWL) for Spain. In terms of the various statistical and econometric methods employed in the study, we used Pearson's $\chi^{2}$ test, and quantile regression and Oaxaca-Blinder wage decomposition.

Results: Although wages for persons with disabilities are lower in social enterprises than in capitalist enterprises, this does not occur in every income distribution percentile. If we also consider employees with similar socio-occupational profiles, SE employees earn more than CE employees. However, the same wage gap exists in PwD employment as it does do in the

\footnotetext{
${ }^{1}$ Corresponding author's email: Virginia.Barba@uclm.es; Telephone: +34 967599200
} 
Spanish labor market in terms of gender, age, level of education, skill level, type of contract, working hours, company size, and sector of activity, both in social and capitalist enterprises.

Conclusion: Results of the study showed that not only, therefore, are SE more sensitive in terms of the labor inclusion of disabled people but they also pursue more positive PwD wage discrimination than $\mathrm{CE}$.

Keywords: Disability equality, Disables people, Social enterprise, Wage gap. JEL Classification: J14, J31, P12, P13, C31.

\section{Introduction}

One of the major preoccupations for human resource management is the disabled wage gap. Most studies undertaken so far, however, have focused on analyzing the wage gap between persons with and those without disabilities (Cervini-Plá, Silva, and Castelló, 2016; Baldwin \& Choe 2014a) rather than among persons with disabilities (Gunderson \& Lee, 2016), or according to the type of company. In this article, we shall compare the wages of persons with disabilities employed in social and capitalist enterprises. The reason for differentiating between these two types of enterprise is that one of the main goals of many social enterprises is to employ and include vulnerable groups (Calderón-Milán, Calderón Milán \& BarbaSánchez, 2020). According to authors such as Clemente et al. (2012) or Pencavel et al. (2006), however, this inclusion has resulted in lower wages.

In recent years, the disabled wage gap in Spain between persons with disabilities and those without disabilities (PwoD) has widened considerably: PwD wages were $10 \%$ lower than PwoD wages in 2010, and 15.7\% lower in 2015 (INE 2010-2015). According to INE data $(2008,2013)$, persons with disabilities also represent a significant, ever-increasing proportion of the total Spanish population, increasing from $8.5 \%$ in 2008 to $16.7 \%$ in 2013. 
This is mainly due to the progressive increase in life expectancy and aging of the Spanish population.

It is for these reasons that Spain has recently implemented a number of socioeconomic policies aimed at the full social inclusion of persons with disabilities (Ministry of Health, Equality and Social Policy 2014), and gainful employment is one of the most effective tools to ensure that persons with disabilities achieve personal autonomy and are fully integrated in the workplace (Law 13/1982). The problem of integration was further aggravated by two additional factors: the fall in PwD employment rate during the 2009-2015 period from $28.3 \%$ to $23.4 \%$ (INE 2009-2015), and the widening disabled wage gap (INE 2010-2015).

On a Spanish legislative level, Articles 39 and 47 of the Royal Legislative Decree 1/2013 refer to the role of social enterprises in creating employment and self-employment opportunities for persons with disabilities, and to the provision of subsidies for the creation of cooperatives and other social enterprises to encourage PwD employment. Authors such as Clemente et al. (2012) or Pencavel, Pistaferri, and Schivardi (2006) highlight the disabled wage gap that exists between social enterprises and capitalist enterprises, which may be due to the fact that social enterprises prioritize labor over capital (Calderón-Milán and CalderónMilán, 2012). It is also necessary to take into account the fact that social enterprises are often formed by restructuring bankrupt or distressed capitalist enterprises into worker-owned firms, or to protect their self-employed partners in the case of worker-owned firms. Although social enterprises prefer to prioritize employment, this may entail a shorter working day and lower wages than in capitalist enterprises. A disabled wage gap also exists within capitalist enterprises, and in 2014 PwD wages were on average 12.5\% lower than PwoD wages in capitalist enterprises in 2014 (INE 2010-2015). 
The main objective of this article is, therefore, to analyze the wage gap that exists among persons with disabilities. Although many studies have analyzed the existing wage gap between persons with and without disabilities both on a national level (Cervini-Plá, Silva, and Castelló, 2016; Malo and Pagán-Rodríguez, 2012) and international level (Baldwin and Choe, 2014b; Charles, 2003; Johnson and Lambrinos, 1985), few have analyzed the existing wage gap among persons with disabilities (Rodríguez, Malo, and Cueto, 2012), or between different types of enterprise (Clemente et al. 2012). Hospido and Moral-Benito (2016) study the wage gap in Spain by gender and type of enterprise (public sector vs. private sector) but they do not distinguish from the point of view of disabled workers (Dwertmann, 2016).

In addition to this main objective, the article provides a number of additional contributions. Firstly, we ascertain whether social enterprises are more sensitive than capitalist enterprises in terms of PwD employment in line with current legislation. In order to do so, we analyzed the main socio-occupational profiles (personal, type of contract, type of company, etc.) of disabled employment in social and capitalist enterprises. Secondly, we examine whether there is a wage gap between persons with disabilities employed by social enterprises and capitalist enterprises according to the different socio-occupational profiles and income distribution percentiles. Thirdly, we use quantile regression and Oaxaca-Blinder decomposition to analyze the extent to which income inequality can be explained by the different socio-occupational profiles of persons with disabilities employed by social and capitalist enterprises, and to what extent it may be due to other factors such as discrimination.

The paper is organized in the following way: Section 2 summarizes the main elements of the theoretical framework; Section 3 presents our methodology; Sections 4 discusses and analyzes the results obtained; and, finally, Section 5 outlines our conclusions and future lines of research. 


\section{Theoretical Framework}

Specialist literature (Baldwin and Johnson, 2000; Mann and Wittenburg, 2015; Cervini-Plá, Silva, and Castelló, 2016) discusses the importance of supporting and encouraging the independence and autonomy of persons with disabilities in their daily lives, and also of them enjoying the same equal opportunities and non-discrimination as any other member of society. As stipulated in Law 13/1982 on the social inclusion of persons with disabilities, one of the most effective tools for achieving personal autonomy and full social inclusion is gainful employment. Social enterprises defend such values and principles (Monzón Campos, 1987; Barea, Juliá, and Monzón, 1999; Pérez Giner, 2003), and so hopefully facilitate employment with more favorable conditions for persons with disabilities than capitalist enterprises. Monzón (2013) describes how social enterprises pursue a single social objective: the social and professional inclusion into employment of vulnerable groups who face exclusion because of insufficient skills or for other reasons. Persons with disabilities are one such vulnerable group who would benefit from easier access to employment in social enterprises irrespective of their socio-demographic profile (sex, age, degree of disability, skills, etc.) (Calderón-Milán and Calderón-Milán, 2012). We therefore formulate the following hypothesis:

Hypothesis 1: Social enterprises are more sensitive than capitalist enterprises to employing persons with disabilities irrespective of their socio-occupational profile.

However, although social enterprises tend to employ more persons with disabilities than capitalist enterprises, wages are generally lower (Clemente et al., 2012; Pencavel, Pistaferri, and Schivardi, 2006). According to the CSWL-CDF 2014 (published by the Spanish Department of Employment and Social Security 2016), SE wages were $12.5 \%$ lower than CE wages in Spain.

From a theoretical point of view and if the disability variable is not taken into account, no clear conclusions can be drawn about the possible relationship between SE and CE wages. 
On the one hand, the nonprofit sector theory defended by authors such as Hansmann (1980), Preston (1989), or Rose-Ackerman (1996) believe SE wages to be lower than CE wages because the employees obtain a series of non-monetary rewards (otherwise known as the intrinsic motivation hypothesis) in addition to their income, such as identification with the company's social objectives or full or stable employment. On the other hand, the theory of the labor-managed firm (LMF) or worker-owned firm, which was first proposed by Ward in 1958 , is that their objective is to maximize wages and salaries rather than company profits unlike capitalist enterprises. Consequently, LMF wages tend to be higher than CE wages. Examples of labor-managed firms in Spain are the workers' cooperative or the worker-owned firm.

Nor is there any consensus from an empirical point of view: although authors such as Pencavel, Pistaferri, and Schivardi (2006), Clemente et al. (2012) or Magne (2017) maintain that SE wages are much lower than CE wages, others such as Burdín and Dean (2009) or Bailly, Chapelle, and Prouteau (2017) believe the opposite to be true. When the PwD group is considered, however, there is empirical evidence to demonstrate that SE wages are lower than CE wages (Rodríguez, Malo, and Cueto, 2012).

Research by Pencavel, Pistaferri, and Schivardi (2006) compared the salaries in Italian worker-owned firms and capitalist enterprises during the 1982-94 period. It revealed that LMF wages were $14 \%$ lower than CE wages and this substantiates the premises of the nonprofit sector theory. The authors Burdín and Dean (2009), on the other hand, obtained opposing results for Uruguay during the 1996-2005 period, which substantiates the premises of the LMF theory.

In the Spanish context, the authors Clemente et al. (2012) analyze the wage gap between cooperatives and capitalist enterprises using the 2007 CSWL. In order to do so, they distinguish between two types of cooperative: the worker-owned cooperative and the non- 
worker-owned cooperative. The authors found that cooperative salaries were generally lower than $\mathrm{CE}$ wages, although it is necessary to qualify this when the type of cooperative, the sector of activity, and the income distribution deciles are taken into account (for this, quantile regression is used). Consequently, although salaries are lower in worker-owned cooperatives than in capitalist enterprises, they are higher in non-worker-owned cooperatives. This fact supports the premises of the nonprofit sector theory in that it is the intrinsic motivations which lead worker-owned companies to lower their salaries in order to maximize employment and job stability. Moreover, although salaries are higher in capitalist enterprises for manufacturing and construction, they are higher in cooperatives for agriculture and services. Finally, the authors state that in worker-owned cooperatives the largest wage gap compared with capitalist enterprises occurs at both ends of income distribution (in the lower and higher deciles), whereas in non-worker-owned cooperatives, wages are higher and the wage gap is more pronounced in the higher income distribution deciles.

In the same vein, Magne (2017) analyzes wages in worker-owned cooperatives and capitalist enterprises in France during the period 2001-2012, and with the exception of years 2001 and 2002, wages were lower in non-worker-owned cooperatives than in capitalist enterprises. On the other hand, and again in the French context, Bailly, Chapelle, and Prouteau (2017) reached the conclusion that wages are higher in non-worker cooperatives than in capitalist enterprises in accordance with the results presented by Burdín and Dean (2009), except in the banking sector where salaries are lower.

If we focus on the group of persons with disabilities, SE wages also appear to be lower than CE wages. In the Spanish context, Rodríguez, Malo, and Cueto (2012) compare PwD wages in special employment centers (SEC), which are a type of social enterprise, and capitalist enterprises from 2008 CSWL data. They conclude that PwD wages are $6.2 \%$ lower in SECs than in capitalist enterprises. This enables us to formulate the following hypothesis: 
Hypothesis 2: Social enterprise wages are lower than capitalist enterprise wages for persons with disabilities.

However, the fact that SE wages are lower does not necessarily mean that there is any evidence of wage discrimination, since this occurs when individuals with the same sociooccupational profile are paid different wages. One of the most common methods for measuring wage discrimination among different groups of people is the Oaxaca-Blinder decomposition technique. A number of articles by various authors address the wage gap that exists, for example, between males and females (Ashraf and Ashraf, 1993; Regan and Oaxaca, 2009; Nakavachara, 2010; Lechmann and Schnabel, 2012; Boll, Rossen, and Wolf, 2017), different age groups (Gannon and Munley, 2009; Mann and Wittenburg, 2015), ethnic minorities and the rest of the population (Ashraf, 1995; Fearon and Wald, 2011; Birch and Marshall, 2018), or between persons with and without disabilities (Johnson and Lambrinos, 1985; Baldwin and Johnson, 1994, 1995, 2000). The Oaxaca-Blinder decomposition technique consists in dividing the wage gap into two components: the component which can be explained by the employee's socio-occupational profile (and which in turn affects productivity), and the unexplained component, which cannot be explained by their profile and which may be due to factors such as discrimination (Blinder, 1973; Oaxaca, 1973).

The pioneering studies by Johnson and Lambrinos (1985) and Baldwin and Johnson (1994, 1995, 2000) analyze the wage gap between persons with and without disabilities. They focused on US data from the years 1971, 1984, and 1990, and include more than a dozen control variables based on the type and severity of the disability. Although in the OaxacaBlinder model, the unexplained component is attributed to discrimination, these studies consider the disability itself to be a source of discrimination. The reason for this is not because there is any desire to discriminate against persons with disabilities and pay them less, but rather because the disability can sometimes cause work limitations or productivity 
differences. In order to distinguish between these, it is necessary to identify two groups within the PwD group: the people who are limited in their daily lives and/or at work, and those who are not. Longhi, Nicoletti, and Platt $(2012,932)$ discuss how DeLeire (2001) perfects this decomposition model by comparing "the wages of those who do not regard their impairment as affecting their work with those who do. The residual wage gap between these two groups is interpreted in terms of productivity, while the residual gap between persons with functional limitations not affecting their work and nondisabled persons is interpreted as discrimination".

Among the studies that consider DeLeire's approach (2001) are the articles by Jones, Latreille, and Sloane (2006) and de Longhi, Nicoletti, and Platt (2012), who focus on the United Kingdom, Gannon and Munley (2009) on Ireland, and Thoursie (2004) on Sweden. All of these authors find empirical evidence to prove that part of the residual wage gap is due not to discrimination but rather to impairment that reduces productivity. In this regard, Longhi et al. (2012) conclude that in the case of the UK, there is no wage discrimination between persons with and without disabilities who are fit to work, with the exception of those with mental illnesses. A further relevant conclusion of these studies is that the wage gap is mainly due to differences in educational qualifications and job-relevant skills between persons with and those without disabilities.

In the same vein, Malo and Pagán-Rodríguez (2012) analyze the wage gap between persons with and without disabilities (who are impaired or unimpaired in their daily lives) in eleven European countries, including Spain, with data from the European Union Household Panel for 1995-2001. The authors reach the conclusion that in most countries, the wages of persons with disabilities who are unimpaired in their daily lives are similar to persons without disabilities, which is why the part of the wage gap that cannot be explained by different characteristics is not due to discrimination but rather to productivity differences caused by the disability in accordance with the other cited studies. 
Finally, in the Spanish context, we should mention the work by Rodríguez, Malo, and Cueto (2012) and Clemente et al. (2012), who use CSWL data from the years 2008 and 2007, respectively, and perform Oaxaca-Blinder decomposition. Rodríguez, Malo, and Cueto (2012), who analyze the wage gap of persons with disabilities working in special employments centers and capitalist enterprises, conclude that $42.1 \%$ of the wage gap can be explained by different individual characteristics and the remaining $57.9 \%$ is due to discrimination. Meanwhile, Clemente et al. (2012), who do not consider the PwD group, analyze the wage gap between social and capitalist enterprises and conclude that social enterprises pay their employees better than capitalist enterprises. From this, it is possible to formulate the following hypothesis:

Hypothesis 3: The socio-occupational profiles of persons with disabilities explain the wage gap between the different types of enterprise.

\section{Methodology}

\subsection{Data and variables}

The data used in this analysis came from the 2014 Continuous Sample of Work Lives which is produced by the Spanish Department of Employment and Social Security (Department of Employment and Social Security, 2016), and Local and National Tax Authorities. The CSWL is compiled from a large database of anonymized microdata which enable working lives to be analyzed and the working population to be represented each year in terms of age, gender, disability, nationality, etc. The data used in this research comes from the 2014 CSWL combined with additional fiscal data (CSWL-CDF). The CSWL is a random sample representing $4 \%$ of persons who contributed to or received contributory benefits from the Spanish social security system at some point in a specific year (the 2014 sample included 1,178,730 individuals). The CSWL contains fiscal information relating to all the earned 
income and revenue for every individual in the sample for each year. If the individual is medically certified as disabled, they need to communicate the degree of disability to their employer in order to obtain the corresponding tax deduction on their personal income or pension. The degree of disability used in our work is based on the medical condition certified by the social security system according to the reduced work capacity. The data contains four states of disability:

a. The individual has no disability or certain limitations, and a degree of disability of below $33 \%$.

b. The individual has a degree of disability of between $33 \%$ and $65 \%$.

c. The individual has a degree of disability of between $33 \%$ and $65 \%$, and requires assistance.

d. The individual has a degree of disability that is equal to or greater than $65 \%$.

We selected persons with disabilities (states of disability b, c, and d) who worked for at least two months in 2014, and who were between the ages of 16 and 65 . Thus, the individuals from our sample are comparable with individuals in the Structure of Earnings Survey from the Eurostat database.

The CSWL contains information about the legal structure of the firms in order to distinguish between social and capitalist enterprises. Appendix A lists the classifications for each type of firm ${ }^{2}$. The report by the Department of Employment and Social Security (2016) contains further information about the content of CSWL microdata.

We collated data for 7,805 persons with disabilities, and of these 3,367 worked for capitalist enterprises, 1,762 worked for social enterprises, and 2,676 worked in the public sector. We eventually removed the public sector employees from the sample because not all

\footnotetext{
${ }^{2}$ In order to perform this classification, Codes F, G, and R are used for social enterprises and special employment centers (SEC), and public limited companies and private limited companies are also included. ***Public administrations are represented by Codes P, Q, and S in Appendix A. Any other company will be classified as a capitalist enterprise.
} 
public sector workers are included in the social security system, and so this group would represent a biased sample.

We calculate income as the annual average wage. In order to take into account the fact that certain individuals might not work a full year, we divide the wages received by the total number of days worked in the year (with additional adjustment for part-time work). We then multiply the figure by 365 to obtain an adjusted measure of the annual wage in full-time equivalent.

In order to prove Hypothesis 1 , it is necessary to measure the sensitivity of each type of enterprise in terms of PwD employment, and three different groups of indicators are used for this purpose:

a. The proportion of PwD employment to total employment for each type of enterprise.

b. The distribution of the total PwD employment periods for the different types of enterprise.

c. The percentage structure of the different socio-occupational profiles for the different types of enterprise: according to the individual's main sociodemographic profile (age, gender, nationality, educational qualifications, disability, etc.) and employment conditions (working hours, type of contract, firm size, labor market sector, and social security contribution group, which determine the individual's occupational category and wage).

To prove Hypotheses 2 and 3, it is necessary to calculate the income for each individual in the sample as an annual average income. 


\subsection{Methods}

In terms of the various statistical and econometric methods employed in the study, we used Pearson's $\chi^{2}$ test to prove Hypothesis 1 , and quantile regression and Oaxaca-Blinder wage decomposition to prove Hypotheses 2 and 3.

To compare social and capitalist enterprises, we use a statistical contrast to measure whether the proportion differences for both types of enterprise are statistically significant using Pearson's $\chi^{2}$ test on the basis of:

H0: all the population proportions are the same

$$
\chi^{2} \text { Pearson }=\sum_{j=1}^{J} \sum_{k=1}^{K} \frac{\left(O_{k j}-E_{k j}\right)^{2}}{E_{k j}}
$$

where $O_{k j}$ is the relative frequency observed for each $k$ sample and $j$ category; $E_{k j}$ is the relative expected frequency for each $k$ sample and $j$ category; $J$ is the total number of categories; and $K$ is the total number of samples. The expected frequencies $(E)$ are calculated from the formula $E=p^{*} O_{\text {total }}$, where $p$ is the sample proportion and $O_{\text {total }}$ is the total frequency observed.

The test statistic is compared with an $\chi^{2}$ of $(J-1) *(K-1)$ degrees of freedom for the intended significance level, and we use a 5\% significance level in our work.

On the other hand, the Oaxaca-Blinder wage decomposition method (1973) was used to calculate how much of the wage gap between functionally different employees in capitalist and social enterprises is not due to differences in their profiles but rather to the different wages received for their profiles (i.e. the different wages for each group).

$$
\bar{w}_{E C}-\bar{w}_{E S}=\left(\bar{X}_{E C}^{\prime} \hat{\beta}_{E C}-\bar{X}_{E S}^{\prime} \hat{\beta}_{E C}\right)+\left(\bar{X}_{E S}^{\prime} \hat{\beta}_{E C}-\bar{X}_{E S}^{\prime} \hat{\beta}_{E S}\right)
$$

Once we have estimated the wage equations for social and capitalist enterprises given the profiles (individual, contract type, company type, etc.), and obtained $\bar{X}_{E C}^{\prime} \hat{\beta}_{E C}$ and $\bar{X}_{E S}^{\prime} \hat{\beta}_{E S}$, respectively, we proceed to calculate a hypothetical wage by considering those persons with 
disabilities employed by social enterprises and supposing that they are employed by capitalist enterprises and paid according to their profiles $\left(\bar{X}_{E S}^{\prime} \hat{\beta}_{E C}\right)$. In view of the wage gap between enterprises $\left(\bar{w}_{E C}-\bar{w}_{E S}\right)$, decomposition is performed by adding two terms: $\left(\bar{X}_{E C}^{\prime}-\bar{X}_{E S}^{\prime}\right) \hat{\beta}_{E C}$ (which is associated with the average differences between the profiles of both PwD groups) and $\bar{X}_{E S}^{\prime}\left(\hat{\beta}_{E C}-\hat{\beta}_{E S}\right)$ (which is related to the different income received by each group of employees because of their profiles).

Following the methodology used in Clemente et al. (2012), we use quantile regression to estimate wage equations since this is considered to be more suitable than the ordinary least squares (OLS) method. Since quantile regression is considered to be a semi-parametric method, it does not require the hypotheses to be proved in terms of the error distribution of the OLS method $\left(u \sim \mathrm{N}\left(0, \sigma^{2} I\right)\right)$. The heteroscedasticity problems that arise in the OLSestimated model are not solved in the wage equations despite taking logarithms of the wage variable, nor is the normal distribution hypothesis proved for the error term of the model $(u)$. Quantile regression can, therefore, solve these problems by estimating different regression lines for the various quantiles of the endogenous variable, and by not requiring the method to use such restrictive assumptions as OLS. Quantile regression is specified as

$$
y=X \beta_{\theta}+u_{\theta}
$$

where $y$ is the endogenous variable, $X$ is the matrix of exogenous variables, $\beta_{\theta}$ is the vector of parameters to calculate for the quantile $\theta$, and $u_{\theta}$ is the random disturbance for quantile $\theta$.

In quantile regression, there are as many $\beta_{\theta}$ vectors as quantiles being considered. It is, therefore, possible to choose quartiles (four vectors), deciles (ten vectors), etc. and we chose to use quartile distribution. The aim of quantile regression is to minimize a sum of asymmetrically-weighted absolute value errors (the weights will inform us which quantile is 
being considered ${ }^{3}$ ). In minimum quadratic estimation, on the other hand, the residual sum of squares (RSS) is minimized. According to Vicens and Sánchez $(2012,8)$, it is necessary to minimize the following expression in quantile regression:

$$
\underset{\beta_{\theta} \in \Re}{\operatorname{Min}}=\left[\sum_{y_{i} \geq X_{i} \beta_{\theta}} \theta\left|y_{i}-X_{i} \beta_{\theta}\right|+\sum_{y_{i}<X_{i} \beta_{\theta}}(1-\theta)\left|y_{i}-X_{i} \beta_{\theta}\right|\right]
$$

where $\theta$ is the quantile ( 0.10 for the first decile, 0.25 for the first quartile, 0.50 for the median, etc.); $y_{i}$ would be the various values taken by sample observations for the endogenous variable; and $\beta_{\theta}$ would be the value which minimizes the expression. It can easily be demonstrated that the estimated $\beta_{\theta}$ value that minimizes the previous expression is that of the observation that leaves a proportion $\theta$ of the sample below and the remaining $1-\theta$ above. The value of $\theta$ is between 0 and 1 , and corresponds to the quantile to be estimated.

\section{Results Analysis}

\subsection{The socio-occupational profiles of persons with disabilities in social and capitalist enterprises}

Given that current Spanish legislation (Spanish Legislative Royal Decree 1/2013) expressly provides for the rights of persons with disabilities and their social inclusion, and also for their employment in social enterprises, social enterprises are hopefully more sensitive than capitalist enterprises to employing persons with disabilities (Hypothesis 1). As we mentioned in the previous section, this greater sensitivity is evident, for example, from the higher proportion of persons with disabilities employed in social enterprises than in capitalist enterprises, and also of persons with socio-occupational profiles that the normal labor market discriminates against (e.g. young persons with lower levels of education and/or fewer skills, or with a higher degree of disability). We therefore comparatively analyze the relative weight

\footnotetext{
${ }^{3}$ For the case of median quantile regression, the weights are symmetrical and we minimize the absolute value errors.
} 
of persons with disabilities in total employment, and also the socio-occupational profiles of persons with disabilities employed by social and capitalist enterprises.

In answer to the first question, according to CSWL-CDF 2014 data (Department of Employment and Social Security 2016), persons with disabilities represent $6.5 \%$ of total SE employment, $1.5 \%$ of total CE employment, and $4.3 \%$ of public sector employment (Table 1 ). The relative weight of persons with disabilities employed in social enterprises is in fact higher than the proportion of persons with disabilities in the potentially active population in Spain (16-64 years) which stands at 4.4\% (INE 2014). This result is a first indicator of social enterprises being more sensitive to employing persons with disabilities than capitalist enterprises.

\section{INSERT TABLE 1 HERE}

Although social enterprises are responsible for around $8 \%$ of total Spanish employment, they concentrate more than a fifth (21.9\%) of total PwD employment periods. This percentage is much higher than expected in terms of their size, and once again reveals their greater propensity to employ persons with disabilities than capitalist enterprises (Table 2).

\section{INSERT TABLE 2 HERE}

In order to descriptively analyze the socio-occupational profiles of persons with disabilities in social and capitalist enterprises, we analyze the percentage of employees with disabilities in both types of enterprise for each socio-occupational characteristic (Tables 3, 5, and 7) in order to determine whether there are any significant statistical differences between 
the two types of enterprise (Tables 4, 6, and 8). There are three types of socio-occupational profile: the individual profile (gender, age, level of education, degree of disability); the employment profile (type of contract, hours, skill level); and the company profile (size and sector of activity).

If we examine the individual profiles of PwD employees (Tables 3 and 4), it is possible to extract the following conclusions from the comparative analysis of social and capitalist enterprises:

- Firstly, there are significant statistical differences in terms of age and degree of disability of employees in social and capitalist enterprises but not in terms of gender and levels of education, which are very similar. The contrast statistics of the equality of proportions hypothesis test are calculated for each variable, and these are shown in Table 4.

- Secondly, although there are no significant differences in PwD gender distribution in percentage terms between social and capitalist enterprises, the distribution does reflect the double discrimination that women with disabilities face: for being female and for being disabled. According to EPA data (2014), although the gender employment gap is small in the Spanish economy and among social enterprises employees (54\% male, $46 \%$ female), PwD employment is clearly male-biased and for every three persons with disabilities who are employed, two are male and one is female.

- Thirdly, the majority of employees with disabilities are in the 24-54 age group, which is where most of the total national employment tends to be concentrated (EPA 2014).

Disabled employees are comparatively younger in social enterprises than in capitalist enterprises (the average age of employees with disabilities in social enterprises is 44 and 46 in capitalist enterprises). Social enterprises tend to provide employment for younger people and more disadvantaged groups, and this again corroborates their greater sensitivity towards employing persons with disabilities. 
- Fourthly, PwD levels of education tend to be quite low since most persons with disabilities have little or no schooling. This is because the current educational system has been slow to provide for persons with disabilities by eliminating all possible barriers.

- Fifthly, and finally, a greater proportion of persons with extremely high degrees of disability (equal to or higher than 65\%) work in social enterprises than in capitalist enterprises. This fact again highlights how social enterprises are more willing to employ persons with disabilities than capitalist enterprises, since it is most difficult for persons with severe disabilities to access and remain in the labor market.

INSERT TABLE 3 HERE

INSERT TABLE 4 HERE

We would like to make the following observations regarding the characteristics of the employment period (Tables 5 and 6):

- Firstly, although most SE and CE contracts are indefinite or full-time, there is greater job stability in social enterprises than in capitalist enterprises since both temporary and parttime employment rates are almost 10 points lower in social enterprises than in capitalist enterprises. These differences are statistically significant and are shown in Table 6.

- Secondly, there are very obvious differences between social and capitalist enterprises in terms of their recruitment of persons with disabilities according to whether a specific disability contract is given or not, since social enterprises are more likely to give this type of contract to employees with disabilities (approximately two thirds of total recruitment). 
In capitalist enterprises, on the other hand, other types of non-specific contracts are predominantly given (more than $80 \%$ of recruitment). These results are corroborated by Pearson's $\chi^{2}$ test and shown in Table 6 .

- Thirdly, there are no significant statistical differences in terms of the distribution of the skill level of disabled employees in social and capitalist enterprises (Table 6). There does tend to be, however, a clear predominance of employees with disabilities who are semiskilled (more than 50\%) and unskilled (around 33\%).

INSERT TABLE 5 HERE

\section{INSERT TABLE 6 HERE}

In terms of the characteristics of the enterprises (Table 7 and 8), we can conclude that:

- Firstly, there are significant statistical differences between social and capitalist enterprises in the distribution of employees with disabilities according to the size of the company and the sector of activity.

- Secondly, in terms of enterprise size, most persons with disabilities are employed by medium-sized and large firms (with more than 50 employees) unlike in Spain where fewer than $2 \%$ of workers work in firms of this size (DIRCE 2014). One possible explanation for this is that in firms with more than 50 workers at least $2 \%$ of all positions must be filled by persons with disabilities according to Law 13/1982 of $7^{\text {th }}$ April for the social inclusion of persons with disabilities. This quota is currently regulated by Article 42 of the 
Spanish Royal Legislative Decree 1/2013. Although most persons with disabilities work in firms with more than 50 employees, there is a higher degree of dispersion in social enterprises than in capitalist enterprises.

- Thirdly, PwD employment is concentrated in a small number of sectors of activity and horizontally segregated. Most persons with disabilities are employed in the services sector and in three branches in particular: health and social services; administrative and support services; and trade activities. These three branches are responsible for half of PwD employment in both social and capitalist enterprises. Although there is a greater concentration of social enterprises in health and social services, there is a greater concentration of capitalist enterprises in administrative and support services. The level of horizontal segregation of $\mathrm{PwD}$ employment is, therefore, quite high.

INSERT TABLE 7 HERE

INSERT TABLE 8 HERE

\subsection{Wages of persons with disabilities in social and capitalist enterprises}

In order to prove Hypothesis 2, we will compare PwD wages in social and capitalist enterprises according to the average and median for the total number of the two types of enterprise, and according to the various socio-occupational profiles (individual, contract type, company type, etc.). We complete our analysis in the following section with income distribution percentiles. 
Analysis of the PwD wage gap between social and capitalist enterprises (Tables 9 and 10) reveals that the wages of persons with disabilities tend to be lower (an average of around $12.5 \%$ and a median of $6 \%{ }^{4}$ ) in social enterprises than in capitalist enterprises except in certain situations. The three exceptions are for persons with disabilities working part time with a specific disability contract, for those working in smaller firms (with fewer than 50 employees), or for those working in the agricultural sector ${ }^{5}$.

INSERT TABLE 9 HERE

\section{INSERT TABLE 10 HERE}

One of the possible reasons why wages are lower in social enterprises is that many such firms (e.g. workers' cooperatives and worker-owned firms) prioritize job creation and preservation over purely financial objectives (including wages). This is because many social enterprises are formed by restructuring distressed capitalist enterprises which are taken over by the workers in order to avoid closures and mass redundancies. Furthermore, in some social enterprises such as consumer cooperatives and producer cooperatives, some of the surpluses that the partners obtain are not derived strictly from wages. The authors Rodríguez, Malo, and Cueto (2012) suggest that one possible reason for lower wages in special employment centers than in capitalist enterprises could be due to differences in the probability of persons with disabilities gaining and maintaining employment in the two types of enterprise, since it may

\footnotetext{
${ }^{4}$ When analyzing the wage gap, account will be taken of the differences in median wages rather than average wages because the median is considered to be a more accurate measure given the great disparity of wages. As a general criterion, the wage gap shown in the tables, therefore, refers to median wages.

${ }^{5}$ The sample size is too small in the agricultural sector to guarantee result validity and robustness.
} 
well be that workers who find employment thanks to the special employment centers would not have been employed in a normal firm (Rodríguez, Malo, and Cueto 2012, 107).

Furthermore, those with more severe disabilities are more likely to find employment through special employment centers (and subsequently in social enterprises) as the data in Table 3 show.

On the other hand, there are fewer social enterprises than capitalist enterprises in industry and construction. Since wages tend to be higher in these two sectors, wages are usually lower in social enterprises than in capitalist enterprises, and as this article shows, this also applies to persons with disabilities.

The same wage gap exists in PwD employment as it does do in the Spanish labor market in terms of gender, age, level of education, skill level, type of contract, working hours, company size, and sector of activity, both in social and capitalist enterprises. The only exception is for persons with disabilities who are employed in smaller social enterprises with fewer than 50 workers, where the wages are higher than in medium-sized and large firms. In social enterprises, therefore, there is no direct correlation between wages and company size. Finally, it is worth mentioning that in social enterprises, persons with disabilities with specific disability contracts earn more than workers with other types of non-specific contracts since the contracts designed to encourage employment among groups at risk of exclusion are generally lower because of the bonuses and/or exemptions for the entrepreneur or employer ${ }^{6}$.

\subsection{Decomposition of the disabled wage gap between social and capitalist enterprises}

We use Oaxaca-Blinder decomposition to further analyze the disabled wage gap that exists in

\footnotetext{
${ }^{6}$ In order to further analyze this result, it would be interesting to see a breakdown of the wage gap between persons with disabilities working in social enterprises and those in capitalist enterprises. This analysis is beyond the scope of this study but will be considered in future lines of research.
} 
social and capitalist enterprises. It has also been possible to prove that the higher average and median wages paid to persons with disabilities in capitalist enterprises than social enterprises hide mixed results if we consider the income decile distribution. Although average wages for persons with disabilities are lower in social enterprises than capitalist enterprises, Figure 1 shows how lower SE wages only occur in the higher deciles of income distribution (in the fifth decile and above). For lower income deciles (first to the fourth decile), persons with disabilities earn more in social enterprises than in capitalist enterprises. The graph also reveals how wage dispersion is lower in social enterprises than in capitalist enterprises.

\section{INSERT FIGURE 1 HERE}

We recommend that quantile regression be used to estimate the wage equations necessary to perform Oaxaca-Blinder decomposition because of the different wage gaps in each type of enterprise. The methodology section of this article details the statisticaleconometric reasons for using these techniques rather than the traditional method of ordinary least squares (OLS).

The daily wages of the persons with disabilities in social and capitalist enterprises were used as the endogenous variables in the equations. Appendix B displays the results of the estimations for each wage equation according to the individual profile, the employment profile, and the company profile. Only those variables with significant parameters for either of the two types of enterprise are included, and variables such as the degree of disability, sector of activity, or age squared are eliminated since these were included in initial models and were found to be irrelevant. The signs of the parameters obtained for each characteristic in the wage equations were as to be expected: men are paid more than women; wages increase with age; higher levels of educations result in higher wages; and the larger the company or the 
longer the length of service, the higher the wage. Employees with temporary contracts earn less than employees with indefinite contracts, and part-time employees are paid less than fulltime employees. Workers with higher skills also earn more. The only variable that obtains clearly different results in both types of enterprise is the variable which indicates whether specific disability contracts have been given or not. While this value is relevant in social enterprises that favor specific disability contracts, it is not as significant and negative for capitalist enterprises (with $10 \%$ significance for the average, and irrelevant for the $25 \%$ quartile and median).

We estimate wage equations for both types of enterprise and these are used for the Oaxaca-Blinder decomposition technique. We are then able to quantify the disabled wage gap between social and capitalist enterprises that is due to the individual profile and which is not, and this enables us to identify the gap caused by discrimination. The results are shown in Table 11, and a positive sign means that the analyzed income or component (with characteristics and discrimination) is greater in capitalist enterprises than in social enterprises, and a negative sign means the opposite.

\section{INSERT TABLE 11 HERE}

From our analysis of Table 11, we can conclude that the results for the average hide a quartile distribution with important differences in terms of the PwD income distribution in each type of enterprise. In the lowest quartile, SE wages are higher than CE wages, whereas in the highest quartile, wages are higher in capitalist enterprises. In each case, the profile is better paid in social enterprises than in capitalist enterprises.

Firstly, as we mentioned before, an analysis of the average wage gap reveals that the daily wage gap is positive (5.34 €/day). This means that wages are lower in social enterprises 
than in capitalist enterprises and is due to differences in employee profiles between the types of enterprise. However, since this figure is greater than the real wage gap (6.63 against 5.34), if $\mathrm{PwD}$ profiles were remunerated in the same way in social enterprises as in capitalist enterprises, the wage gap would be even greater. On the other hand, the other wage component is negative, and this indicates that $\mathrm{PwD}$ profiles are paid higher in social enterprises than in capitalist enterprises (the value of this component is $-1.29 € /$ day). It is evident, therefore, that there is no wage discrimination for persons with disabilities in social enterprises, although there is positive wage discrimination since the PwD profiles are paid better in social enterprises than in capitalist enterprises. In terms of the different quartiles, these same conclusions are confirmed for quartiles $50 \%$ and $75 \%$ of income distribution, where wages are higher in capitalist enterprises than in social enterprises.

This conclusion is not corroborated for the first quartile (quartile 25) of income distribution where earnings are higher in social enterprises than in capitalist enterprises. The results also indicate that in terms of the profiles of persons with disabilities employed by social enterprises, the wage gap should benefit capitalist enterprises whereas this is not the case.

We can, therefore, confirm that regardless of the quartile considered, social enterprises remunerate their employees according to their socio-occupation profiles better than capitalist enterprises. If we compare how much employees are paid in both types of enterprise according to their profiles, it is evident that they would always earn less in capitalist enterprises, and so we can confirm that social enterprises do engage in positive wage discrimination.

\section{Conclusions}

Social enterprises have a number of inherent factors that make them more sensitive than 
capitalist enterprises to employing disadvantaged groups or those at risk of social exclusion, and these include persons with disabilities. Although there is more PwD employment in social enterprises than in capitalist enterprises (6.5\% against $1.5 \%)$, the results only partly reveal this greater sensitivity and only partially prove our first hypothesis since we have observed that there are significant statistical differences in the distribution of PwD employment between the types of enterprise according to the degree of disability, type of contract and working hours. There are, therefore, more persons with serious disabilities working in social enterprises than in capitalist enterprises, and there is also greater job stability for persons with disabilities since there are fewer temporary or part-time contracts than in capitalist enterprises. Nevertheless, there are no significant statistical differences in the distribution of PwD employment according to gender or skill level, and so, in this respect, it is not possible to observe any greater sensitivity in social enterprises than in capitalist enterprises in terms of the employment of either woman with disabilities or less skilled workers with disabilities in both types of enterprise. It is, therefore, essential to establish support and awareness policies to encourage enterprises to adapt the workplace to the needs and requirements of their employees with disabilities, and for gender equality and social inclusion policies to be developed for persons with disabilities in line with the recommendations of Brooks (2018).

Our results also reveal that PwD wages (both in terms of the average and the median) are lower in social enterprises than in capitalist enterprises, and this proves the second hypothesis. Generally speaking, wages are also lower in social enterprises than in capitalist enterprises for most of the socio-occupational profiles analyzed with three exceptions: those working part-time with specific disability contracts; those working in small enterprises; or those working in the agricultural sector. Furthermore, we believe that employees prioritize job stability over higher wages, as defined in the nonprofit sector theory. 
When income distribution is divided into deciles, however, these lower SE wages only occur in the higher deciles (in the fifth decile and above). In the lower wage deciles (the first to the fourth deciles), on the other hand, persons with disabilities earn more in social enterprises than they do in capitalist enterprises. There is also less wage dispersion in social enterprises than there is in capitalist enterprises. These results contradict the generalized perception that $\mathrm{SE}$ wages are lower than $\mathrm{CE}$ wages, and highlight the important social work of this type of enterprise.

Finally, using Oaxaca-Blinder decomposition, we were able to prove that in every income distribution quartile considered social enterprises pay their employees more in terms of their individual socio-occupational profiles than capitalist enterprises. We can, therefore, conclude that the wage gap between the different types of enterprise is more linked to differences in the socio-occupational profiles of persons with disabilities (such as the skill level, in particular) than to wage discrimination in line with the results presented by Jones, Latreille, and Sloane (2006), or Malo and Pagán-Rodríguez (2012). The third hypothesis highlights the need for inclusive educational policies to ensure that persons with disabilities are able to continue with their education, and for other measures to encourage enterprises to adapt the workplace to the needs and requirements of their PwD employees so that their disability does not limit their ability to work, their performance, or their wages.

In terms of future lines of research and given the limited information contained in CSWL-CDF 2014 to explain segmented labor markets and wage discrimination, there is a real need for future data sets to gather further information about the types and levels of disability as Morris and Zaidi (2020) propose, and particularly individual and employment profiles, and the career advancement opportunities open to persons with and without disabilities. Further interesting lines of research would be to analyze the various sectors of activity in order to establish whether differences exist as Clemente et al. (2012) suggest, or to study other 
countries with similar databases in order to compare and generalize the results in this work as Malo and Pagán-Rodríguez (2012) propose.

\section{Declarations}

Ethics approval and consent to participate: Not applicable.

Consent for publication: The authors consent for publication.

Availability of data and material: The data used in this study was obtained from the public database Continuous Sample of Work Lives which is produced by the Spanish Department of Employment and Social Security

(http://www.segsocial.es/wps/portal/wss/internet/EstadisticasPresupuestosEstudios/Estadistica $\underline{\mathrm{s} / \mathrm{EST} 211})$.

Competing interests: The authors declare no conflict of interest.

Funding: This work has been financed by the Universidad de Castilla-La Mancha (Spain) and co-financed by the European Regional Development Fund, through support to the ENSITMA Research Group (2020-GRIN-28793).

Authors' contributions: This article is the product of a joint reflection. However, Sections 2 and 3.1 have been written by Beatriz Calderón-Milán, Sections 3.2 and 4.3 have been written by María José Calderón-Milán, Sections 4.1 and 4.2 have been written by Virginia BarbaSánchez while Sections 1 and 5 have been written jointly.

Acknowledgements: We would like to thank to Dr. Melanie Jones for helpful and constructive comments on an earlier draft.

\section{References}

Ashraf, J. (1995). The effect of race on earnings in the United States. Applied Economics Letters, 2, 72-75. doi: 10.1080/135048595357609. 
Ashraf, J., \& Ashraf, B. (1993). An analysis of the male-female earnings differential in Pakistan. Pakistan Development Review, 32, 895-902.

Bailly, F., Chapelle, K., \& Prouteau, L. (2017). Wage differentials between conventional firms and non-worker cooperatives: Analysis of evidence from France. Competition and Change, 21, 321-341. doi: 10.1177/1024529417713769.

Baldwin, M. L., \& Johnson, W. C. (1994). Labor market discrimination against men with disabilities. Journal of Human Resources, 29 (1),1-19.

Baldwin, M. L. \& Johnson, W. C. (1995). Labor market discrimination against women with disabilities. Industrial Relations, 34 (4), 555-577.

Baldwin, M. L., \& Johnson, W. C. (2000). Labor market discrimination against men with disabilities in the year of the ADA. Southern Economic Journal, 66 (January), 548566.

Baldwin, M. L., \& Choe, Ch. (2014a). Re-examining the models used to estimate disabilityrelated wage discrimination. Applied Economics, 46, 1393-1408. doi: 10.1080/00036846.2013.872762.

Baldwin, M. L., \& Choe, Ch. (2014b). Wage Discrimination Against Workers with Sensory Disabilities. Industrial Relation, 53, 101-124. doi: 10.1111/irel.12048.

Barea, J., Juliá, J. F., \& Monzón, J. L. (1999). Grupos empresariales de la economia social en España: Ciriec-España y Ministerio de Trabajo y Asuntos Sociales.

Birch, E., \& Marshall, D. (2018). Revisiting the earned income gap for Indigenous and nonIndigenous Australian workers: Evidence from a selection bias corrected model. Journal of Industrial Relations, 60, 3-29. doi: 10.1177/0022185617732365.

Blinder, A. S. (1973). Wage discrimination: reduced form and structural estimates. Journal of Human Resources, 8, 436-455. 
Boll, C., Rossen, A., \& Wolf, A. (2017). The EU Gender Earnings Gap: Job Segregation and Working Time as Driving Factors. Jahrbucher fur Nationalokonomie und Statistik, 237, 407-452. doi: 10.1515/jbnst-2017-0100.

Brooks, J. D. (2018). Just a Little Respect: Differences in Job Satisfaction Among Individuals With and Without Disabilities. Social Sciences Quarterly, 100(1), 379-388. doi: $10.1111 /$ ssqu. 12543

Burdín, G., \& Dean, A. (2009). New evidence on wages and employment in worker cooperatives compared with capitalist firms. Journal of Comparative Economic, 37, 517-533.

Calderón-Milán, B., \& Calderón-Milán, M. J. (2012). La calidad del empleo en las entidades de la economía social en período de crisis. Ekonomiaz, 79(1), 30-57.

Calderón-Milán, M. J., Calderón-Milán, B., \& Barba-Sánchez, V. (2020). Labour Inclusion of People with Disabilities: What Role Do the Social and Solidarity Economy Entities Play? Sustainability, 12(3), 1079. doi: 10.3390/su12031079.

Cervini-Plá, M., Silva, J. I., \& Vall-Castelló, J. (2016). Estimating the income loss of disabled individuals: the case of Spain. Empirical Economics, 51, 809-829. doi: 10.1007/s00181-015-1019-7.

Charles, K. K. (2003). The Longitudinal Structure of Earnings Losses among Work-Limited Disabled Workers. The Journal of Human Resources, 38, 618. doi: 10.2307/1558770. Clemente, J, Díaz-Foncea, M., Marcuello,C. \& Sanso-Navarro, M. (2012). The wage gap between cooperative and capitalist firms: evidence from Spain. Annals of Public and Cooperative Economics, 83, 337-356.

DeLeire, Th. (2001). Changes in Wage Discrimination against People with Disabilities: 198493. The Journal of Human Resources, 36, 144. doi: 10.2307/3069673.

DIRCE (2014). Directorio Central de Empresas. Instituto Nacional de Estadística (INE). 
Dwertmann, D. J. G. (2016). Management research on disabilities: Examining methodological challenges and possible solutions. International Journal of Human Resource Management, 27 (14): 1477-1509. doi: 10.1080/09585192.2015.1137614.

EPA (2014). Encuesta de Población Activa. Instituto Nacional de Estadística.

Fearon, G., \& Wald, S. (2011). The earnings gap between black and white workers in Canada: Evidence from the 2006 census. Relations Industrielles, 66, 324-348. doi: $10.7202 / 1006342$ ar.

Gannon, B., \& Munley, M. (2009). Age and disability: Explaining the wage differential. Social Science and Medicine, 69, 47-55. doi: 10.1016/j.socscimed.2009.04.013.

Gunderson, M., \& Byron, Y. L. (2016). Pay discrimination against persons with disabilities: Canadian evidence from PALS. International Journal of Human Resource Management, 27(14), 1531-1549. doi: 10.1080/09585192.2015.1072106.

Hansmann, H. B. (1980). The role of nonprofit enterprise. The Yale law journal, 89(5), 835901.

Hospido, L., \& Moral-Benito, E. (2016). The public sector wage premium in Spain: Evidence form longitudinal administrative data. Labour Economics, 42, 101-122

INE (2008). Encuesta sobre discapacidades autonomía personal y situaciones de dependencia 2008 (EDAD2008). Instituto Nacional de Estadística.

INE (2009-2015). El empleo de las personas con discapacidad. Instituto Nacional de Estadística.

INE (2010-2015). El salario de las personas con discapacidad. Instituto Nacional de Estadística.

INE (2013). Encuesta de Integración Social y Salud, 2012. Instituto Nacional de Estadística. INE (2014). El empleo de las personas con discapacidad. Instituto Nacional de Estadística. 
Johnson, W. G., \& Lambrinos, L. (1985). Wage discrimination against handicapped men and women. Journal of Human Resources, 20(2), 264-277.

Jones, M. K., Latreille, P. L., and Sloane, P. J. (2006). Disability, gender, and the British labour market. Oxford Economic Papers, 58, 407-449. doi: 10.1093/oep/gpl004.

Lechmann, D. S., \& Schnabel, C. (2012). Why is there a gender earnings gap in selfemployment? A decomposition analysis with German data. IZA Journal of European Labor Studies, 1. doi: 10.1186/2193-9012-1-6.

Ley 13/1982. de 7 de Abril, de Integración Social de los Minusválidos (LISMI). Edited by Jefatura del Estado: BOE.

Longhi, S., Nicoletti, Ch., \& Platt, L. (2012). Interpreting wage gaps of disabled men: the roles of productivity and of discrimination. Southern Economic Journal, 78, 931-953. doi: 10.4284/0038-4038-78.3.931.

Magne, N. (2017). Wage inequality in workers' cooperatives and conventional firms. European Journal of Comparative Economics, 14 (2), 303-329. doi: 10.25428/18242979/201702-303-329.

Malo, M. Á., \& Pagán-Rodríguez, R. (2012). Diferencias salariales y discapacidad en Europa: ¿discriminación o menor productividad? Revista Internacional del Trabajo, 131(1-2), 47-66.

Mann, D. R., \& Wittenburg, D.C. (2015). Starting Behind: Wage and Employment Differentials Between Young Adults with and without Disabilities. Journal of Disability Policy Studies, 26, 89-99. doi: 10.1177/1044207315583898.

Ministerio de Empleo y Seguridad Social (2016). La Muestra Continua de Vidas Laborales. Edited by Seguridad Social. Madrid. 
Ministerio de Sanidad Servicios Sociales e Igualdad (2014). Plan de Acción de la Estrategia Española sobre Discapacidad 2014-2020. Edited by Dirección General de Políticas de Apoyo a la Discapacidad. Secretaría de Estado de Servicios Sociales e Igualdad.

Monzón, J. L. (1987). La economía social en España. CIRIEC-España. Revista de Economía Pública, Social y Cooperativa: 19-30.

Monzón, J. L. (2013). Empresas sociales y economía social: perímetro y propuestas metodológicas para la medición de su impacto socioeconómico en la UE. Revista de Economía Mundial, 35, 151-164.

Morris, Z. A., \& Zaidi, A. (2020). Estimating the extra costs of disability in European countries: Implications for poverty measurement and disability-related decommodification. Journal of European Social Policy, 1-16. doi: $10.1177 / 0958928719891317$.

Nakavachara, V. (2010). Superior female education: Explaining the gender earnings gap trend in Thailand. Journal of Asian Economics, 21, 198-218. doi:

10.1016/j.asieco.2009.09.006.

Oaxaca, R. (1973). Male-female wage differentials in urban labor markets. International Economic Review, 14, 693-709.

Pencavel, J., Pistaferri, L., \& Schivardi, F. (2006). Wages, employment, and capital in capitalist and worker-owned firms. Industrial and Labor Relations Review, 60, 23-44.

Pérez-Giner, F. (2003). La economía social: sus claves. CIRIEC España.

Preston, A. E. (1989). The nonprofit worker in a for-profit world. Journal of labor economics, 7(4), 438-463.

Regan, T. L., \& Oaxaca, R.L. (2009). Work experience as a source of specification error in earnings models: implications for gender wage decompositions. Journal of Population Economics, 22, 463-499. 
Rodríguez, V., Malo, M. A., \& Cueto, B. (2012). Diferencias salariales por discapacidad y Centros Especiales de Empleo. Cuadernos de Economía, 35, 100-116.

Rose-Ackerman, S. (1996). Altruism, nonprofits, and economic theory. Journal of economic literature, 34(2), 701-728.

Spanish Royal Legislative Decree 1/2013. Texto Refundido de la Ley General de derechos de las personas con discapacidad y de su inclusión social. Edited by Ministerio de Sanidad Servicios Sociales e Igualdad: BOE n. 289 (2013/12/03).

Thoursie, P. S. (2004). Occupational attainment and earnings: The case of the disabled. Labour, 18, 415-442. doi: 10.1111/j.1121-7081.2004.00276.x.

Vicens, J., \& Sánchez, B. (2012). Regresión cuantílica: estimación y contrastes. Instituto L.R. Klein-Centro Gauss. Working paper of Autónoma University of Madrid 21 (April).

Ward, B. (1958). The firm in Illyria: market syndicalism. The American Economic Review, 48(4), 566-589.

\section{Appendix A}

INSERT TABLE A1 HERE

INSERT TABLE A2 HERE

Appendix B. Results of the quantile estimations of wage equations for social and capitalist enterprises 
INSERT TABLE B1 HERE

INSERT TABLE B2 HERE 


\section{Table 1}

Distribution of employees with disabilities according to the type of enterprise (\% of total employment of persons with and without disabilities)

\begin{tabular}{|l|l|}
\hline Social enterprises (SE) & $6.5 \%$ \\
\hline Capitalist enterprises (CE) & $1.5 \%$ \\
\hline Public sector & $4.3 \%$ \\
\hline Total & $2.4 \%$ \\
\hline
\end{tabular}

Source: Compiled by the authors based on CSWL2014 
Table 2

Distribution of employment periods of persons with and without disabilities in the different types of enterprise (\% of total employment periods for each group)

\begin{tabular}{|l|c|c|}
\hline & Persons with disabilities & Persons without disabilities \\
\hline Social enterprises & $21.9 \%$ & $7.7 \%$ \\
\hline Capitalist enterprises & $45.5 \%$ & $74.6 \%$ \\
\hline Public sector & $32.6 \%$ & $17.6 \%$ \\
\hline Total & $100.0 \%$ & $100.0 \%$ \\
\hline
\end{tabular}

Source: Compiled by the authors based on CSWL2014 
Table 3

Distribution of persons with disabilities according to their individual profiles in social and capitalist enterprises

\begin{tabular}{|c|c|c|}
\hline & $\begin{array}{c}\text { Social } \\
\text { Enterprises } \\
\end{array}$ & $\begin{array}{c}\text { Capitalist } \\
\text { Enterprises } \\
\end{array}$ \\
\hline \multicolumn{3}{|l|}{$\%$ according to sex } \\
\hline Male & $62.7 \%$ & $63.7 \%$ \\
\hline Female & $37.3 \%$ & $36.3 \%$ \\
\hline Total & $100.0 \%$ & $100.0 \%$ \\
\hline \multicolumn{3}{|l|}{$\%$ according to age range } \\
\hline Under $25^{*}$ & $2.0 \%$ & $1.8 \%$ \\
\hline $25-39$ & $31.8 \%$ & $25.5 \%$ \\
\hline $40-54$ & $48.5 \%$ & $51.2 \%$ \\
\hline 55 and above & $17.7 \%$ & $21.5 \%$ \\
\hline Total & $100.0 \%$ & $100.0 \%$ \\
\hline Average age & 44 & 46 \\
\hline \multicolumn{3}{|l|}{$\%$ according to level of education (1) } \\
\hline No education & $24.3 \%$ & $23.5 \%$ \\
\hline Primary education & $45.4 \%$ & $46.4 \%$ \\
\hline Secondary education & $21.6 \%$ & $22.7 \%$ \\
\hline Higher education & $8.7 \%$ & $7.4 \%$ \\
\hline Total & $100.0 \%$ & $100.0 \%$ \\
\hline \multicolumn{3}{|l|}{$\%$ according to degree of disability } \\
\hline Between $33 \%$ and $65 \%$ & $80.7 \%$ & $85.9 \%$ \\
\hline $\begin{array}{l}\text { Between } 33 \% \text { and } 65 \% \text { with proof of requiring } \\
\text { assistance, or reduced mobility* }\end{array}$ & $2.5 \%$ & $2.6 \%$ \\
\hline Equal to or greater than $65 \%$ & $16.8 \%$ & $11.5 \%$ \\
\hline Total & $100.0 \%$ & $100.0 \%$ \\
\hline
\end{tabular}

Source: Compiled by the authors based on CSWL2014

* Fewer than 50 individuals in the sample

Note (1): Data for the level of education variable that appears in the CSWL are from the

Municipal Register of Inhabitants. Since these data do not always offer the most up-to-date information about every individual, this variable is not totally reliable. 


\section{Table 4}

Chi-squared equality of proportions test to compare social and capitalist enterprises according to individual characteristics

\begin{tabular}{|l|r|l|l|}
\hline Analyzed variable & $\begin{array}{l}\text { Calculated } \\
\text { value }\end{array}$ & $\begin{array}{l}\text { Degrees of } \\
\text { freedom }\end{array}$ & $\begin{array}{l}\text { Asymptotic significance }(2 \\
\text { sides) }\end{array}$ \\
\hline Sex & 0.52 & 1 & .471 \\
Age range & 27.31 & 3 & .000 \\
Level of education & 3.54 & 3 & .315 \\
Degree of disability & 27.88 & 2 & .000 \\
\hline
\end{tabular}

Source: Compiled by the authors 


\section{Table 5}

Distribution of PwD employment periods in social and capitalist enterprises according to contract characteristics

\begin{tabular}{|l|r|r|}
\hline & Social enterprises & Capitalist enterprises \\
\hline \% according to type of contract & $84.0 \%$ & $74.3 \%$ \\
\hline Indefinite & $16.0 \%$ & $25.7 \%$ \\
Temporary & $100.0 \%$ & $100.0 \%$ \\
Total & $77.7 \%$ & $68.5 \%$ \\
\hline$\%$ according to type of working day & $22.3 \%$ & $31.5 \%$ \\
\hline Full time & $100.0 \%$ & $100.0 \%$ \\
Part time & $38.7 \%$ & $82.6 \%$ \\
Total & $61.3 \%$ & $17.4 \%$ \\
\hline \% specific disability contract & $100.0 \%$ & $100.0 \%$ \\
\hline Other types of contract & $11.4 \%$ & $9.7 \%$ \\
Specific disability contract & $55.5 \%$ & $56.6 \%$ \\
Total & $33.1 \%$ & $33.6 \%$ \\
\hline$\%$ according to skill level & $100.0 \%$ & $100.0 \%$ \\
\hline Highly skilled & \\
Semi-skilled & \multicolumn{2}{|c|}{} \\
Unskilled &
\end{tabular}

Source: Compiled by the authors from CSWL2014 


\section{Table 6}

Chi-squared tests for equality of proportions to compare social and capitalist enterprises according to the type of contract

\begin{tabular}{|c|c|c|c|}
\hline Analyzed variable & $\begin{array}{l}\text { Calculated } \\
\text { value }\end{array}$ & $\begin{array}{l}\text { Degrees of } \\
\text { freedom }\end{array}$ & $\begin{array}{c}\text { Asymptotic significance (2 } \\
\text { sides) }\end{array}$ \\
\hline Type of contract & 67.44 & 1 & .000 \\
\hline Type of working day & 51.73 & 1 & .000 \\
\hline Specific disability contract & $1,118.13$ & 1 & .000 \\
\hline Skill level & 3.98 & 2 & .136 \\
\hline
\end{tabular}

Source: Compiled by the authors 


\section{Table 7}

Distribution of PwD employment periods for social and capitalist enterprises according to size and sector

\begin{tabular}{|l|r|r|}
\hline \multicolumn{2}{|c|}{ Social enterprises } & Capitalist enterprises \\
\hline$\%$ according to size & $47.3 \%$ & $37.1 \%$ \\
\hline Fewer than 50 workers & $15.4 \%$ & $14.7 \%$ \\
Between 50 and 99 workers & $37.3 \%$ & $48.2 \%$ \\
100 and more workers & $100.0 \%$ & $100.0 \%$ \\
Total & \multicolumn{2}{|c|}{} \\
\hline \% according to activity sector & $0.9 \%$ & $0.7 \%$ \\
\hline Agriculture* & $15.5 \%$ & $20.3 \%$ \\
Industry & $2.8 \%$ & $3.6 \%$ \\
Construction & $80.7 \%$ & $75.4 \%$ \\
Services & $22.6 \%$ & $8.5 \%$ \\
Health and social services & $12.8 \%$ & $28.0 \%$ \\
Administrative and support services & $12.5 \%$ & $13.0 \%$ \\
Trade activities & $32.8 \%$ & $25.9 \%$ \\
Other services & $100.0 \%$ & $100.0 \%$ \\
Total & & \\
\hline
\end{tabular}

Source: Compiled by the authors from CSWL2014

* There are fewer than 50 individuals in the sample. 


\section{Table 8}

Chi-squared equality of proportions tests to compare social and capitalist enterprises according to firm characteristics

\begin{tabular}{|l|r|c|c|}
\hline Analyzed variable & Calculated value & Degrees of freedom & \multicolumn{2}{|c|}{$\begin{array}{c}\text { Asymptotic significance (2 } \\
\text { sides) }\end{array}$} \\
\hline Firm size & 65.72 & 2 & 0.000 \\
Sector of activity & 22.52 & 3 & 0.000 \\
Only service sectors & 323.90 & 3 & 0.000 \\
\hline
\end{tabular}

Source: Compiled by the authors 


\section{Table 9}

Annual Full-Time Equivalent (FTE) income of persons with disabilities for social and capitalist enterprises according to individual profile

\begin{tabular}{|c|c|c|c|}
\hline & $\begin{array}{c}\text { Social } \\
\text { enterprises }\end{array}$ & $\begin{array}{c}\text { Capitalist } \\
\text { enterprises }\end{array}$ & $\begin{array}{c}\text { Wage gap } \\
\text { (1) }\end{array}$ \\
\hline \multicolumn{4}{|l|}{ Total FTE income } \\
\hline Income (€/year) (Average) & 16,790 & 19,172 & $-12.4 \%$ \\
\hline FTE income (€/year) (Average) & 20,971 & 26,880 & $-22.0 \%$ \\
\hline FTE income (€/year) (Median) & 15,840 & 16,859 & $-6.0 \%$ \\
\hline \multicolumn{4}{|l|}{ FTE income according to sex (€/year) } \\
\hline Male & 16,131 & 17,825 & $-9.5 \%$ \\
\hline Female & 15,253 & 15,680 & $-2.7 \%$ \\
\hline \multicolumn{4}{|l|}{ FTE income according to age range (€/year) } \\
\hline Under 25 years* & 9,279 & 12,383 & $-25.1 \%$ \\
\hline 25 - 39 years & 14,861 & 15,533 & $-4.3 \%$ \\
\hline $40-54$ years & 16,178 & 16,582 & $-2.4 \%$ \\
\hline 55 and over & 17,082 & 20,443 & $-16.4 \%$ \\
\hline \multicolumn{4}{|c|}{ FTE income according to level of education (€/year) (2) } \\
\hline No education & 13,118 & 15,104 & $-13.1 \%$ \\
\hline Primary education & 15,158 & 16,177 & $-6.3 \%$ \\
\hline Secondary education & 18,558 & 19,359 & $-4.1 \%$ \\
\hline Higher education & 26,343 & 27,149 & $-3.0 \%$ \\
\hline \multicolumn{4}{|l|}{ FTE income according to degree of disability } \\
\hline Between $33 \%$ and $65 \%$ & 16,021 & 16,977 & $-5.6 \%$ \\
\hline $\begin{array}{l}\text { Between } 33 \% \text { and } 65 \% \text { with proof of requiring } \\
\text { assistance, or reduced mobility* }\end{array}$ & 17,746 & 18,828 & $-5.7 \%$ \\
\hline Equal to or greater than $65 \%$ & 14,617 & 15,511 & $-5.8 \%$ \\
\hline
\end{tabular}

Source: Compiled by the authors from CSWL-CDF 2014 data

Notes: We calculate median wages because of the great disparity of data.

* There are fewer than 50 individuals in the sample.

(1) The wage gap for each group is calculated as $\left(\frac{\text { Income } S E}{\text { Income } C E}-1\right) * 100$

(2) Data for the level of education variable that appears in the CSWL are from the Municipal Register of Inhabitants. Since these data do not always offer the most up-to-date information about every individual, this variable is not totally reliable. 
Table 10

Annual income of persons with disabilities in social and capitalist enterprises according to type of contract and type of firm

\begin{tabular}{|c|c|c|c|}
\hline & $\begin{array}{l}\text { Social } \\
\text { enterprises }\end{array}$ & $\begin{array}{l}\text { Capitalist } \\
\text { enterprises }\end{array}$ & $\begin{array}{l}\text { Wage gap } \\
\text { (1) }\end{array}$ \\
\hline \multicolumn{4}{|c|}{ FTE income according to type of contract (€/year) } \\
\hline Indefinite & 16.334 & 17.798 & $-8,2 \%$ \\
\hline Temporary & 13.193 & 14.358 & $-8,1 \%$ \\
\hline \multicolumn{4}{|c|}{ Income according to working hours (€/year) (2) } \\
\hline Full time & 15.838 & 17.527 & $-9,6 \%$ \\
\hline Part time & 8.935 & 8.486 & $5,3 \%$ \\
\hline \multicolumn{4}{|c|}{ FTE income according to specific disability contract (€/year) } \\
\hline Other type of contract & 13.442 & 17.553 & $-23,4 \%$ \\
\hline Specific disability contract & 16.545 & 14.705 & $12,5 \%$ \\
\hline \multicolumn{4}{|c|}{ FTE income according to skill level (€/year) } \\
\hline Highly skilled & 30.700 & 36.037 & $-14,8 \%$ \\
\hline Semi-skilled & 16.579 & 18.116 & $-8,5 \%$ \\
\hline Unskilled & 11.571 & 13.595 & $-14,9 \%$ \\
\hline \multicolumn{4}{|c|}{ FTE income according to the type of firm (€/year) } \\
\hline Fewer than 50 workers & 16.128 & 15.999 & $0,8 \%$ \\
\hline Between 50 and 99 workers & 14.908 & 16.410 & $-9,2 \%$ \\
\hline 100 and more workers & 15.728 & 18.043 & $-12,8 \%$ \\
\hline \multicolumn{4}{|c|}{ FTE income according to sector of activity ( $€ /$ year) } \\
\hline Agriculture* & 14.000 & 13.705 & $2,2 \%$ \\
\hline Industry & 17.253 & 21.073 & $-18,1 \%$ \\
\hline Construction & 17.964 & 20.275 & $-11,4 \%$ \\
\hline Services & 15.324 & 15.819 & $-3,1 \%$ \\
\hline Health and social services & 12.994 & 13.534 & $-4,0 \%$ \\
\hline $\begin{array}{l}\text { Administrative and support } \\
\text { services }\end{array}$ & 13.924 & 14.432 & $-3,5 \%$ \\
\hline Trade activities & 16.231 & 17.586 & $-7,7 \%$ \\
\hline
\end{tabular}

Source: Compiled by the authors from CSWL-CDF 2014

Notes: * There are fewer than 50 individuals in the sample.

(1) The wage gap for each group is calculated as $\left(\frac{\text { Income } S E}{\text { Income CE }}-1\right) * 100$

(2) In order to calculate income according to working hours, the full-time equivalent adjustment has been applied to see the differences between the two types of enterprise. 
Table 11

Decomposition of the wage gap between social and capitalist enterprises

\begin{tabular}{|l|r|r|r|r|}
\hline & Mean & \multicolumn{1}{c|}{$\begin{array}{c}\text { Quartile } \\
25 \%\end{array}$} & $\begin{array}{c}\text { Quartile } \\
50 \%\end{array}$ & \multicolumn{1}{c|}{$\begin{array}{c}\text { Quartile } \\
75 \%\end{array}$} \\
\hline Gap in daily wages & 5.34 & -3.09 & 0.78 & 7.07 \\
\hline Gap according to profile & 6.63 & 2.27 & 4.95 & 8.68 \\
\hline Gap according to discrimination & -1.29 & -5.36 & -4.17 & -1.61 \\
\hline
\end{tabular}

Source: Compiled by the authors 
Table A1. Codes of the legal status of employers considered in the CSWL

\begin{tabular}{|c|l|}
\hline \multicolumn{2}{|c|}{ LEGAL STATUS OF THE EMPLOYER } \\
\hline Code & \multicolumn{1}{|c|}{ Type of legal entity } \\
\hline A & Public limited companies \\
\hline B & Private limited companies \\
\hline C & General partnerships \\
\hline D & Limited partnerships \\
\hline E & Jointly owned companies \\
\hline F & Cooperative companies \\
\hline G & Associations and other non-defined types \\
\hline H & Condominium homeowners associations \\
\hline J & Non-commercial partnerships with or without independent legal status \\
\hline N & Foreign entities \\
\hline P & Local corporations \\
\hline Q & Public institutions \\
\hline R & Religious congregations or institutions \\
\hline &
\end{tabular}

Table A2. Special groups with differentiated Social Security contribution rates included in the CSWL

\begin{tabular}{|c|l|}
\hline Code & \multicolumn{1}{|c|}{ Name } \\
\hline 0100 & Government Departments \\
\hline 0110 & $\begin{array}{l}\text { Public Sector Agencies and Bodies (National, Autonomous, and Local); Councils, } \\
\text { Courts, Social Security Entities, Parliaments }\end{array}$ \\
\hline 0120 & $\begin{array}{l}\text { Public Sector Foundations and Companies (National, Autonomous, and Local); } \\
\text { Companies in which the Public Sector has a majority shareholding, Public } \\
\text { Banking, Bank of Spain }\end{array}$ \\
\hline 1303 & Subsidized Educational Centers \\
\hline 2200 & Local Administration (including Consortiums and Associations) \\
\hline 2600 & Autonomous Administration (including Universities and Consortiums) \\
\hline 2601 & Health and Social Services Centers \\
\hline 4100 & Unemployed and Public Employment Services \\
\hline 5081 & Temporary Employment Agencies \\
\hline 5161 & Workers' Cooperatives \\
\hline 5180 & Worker-owner public and private limited companies \\
\hline 9999 & Others \\
\hline
\end{tabular}


Table B1. Wage equation estimations for social enterprises

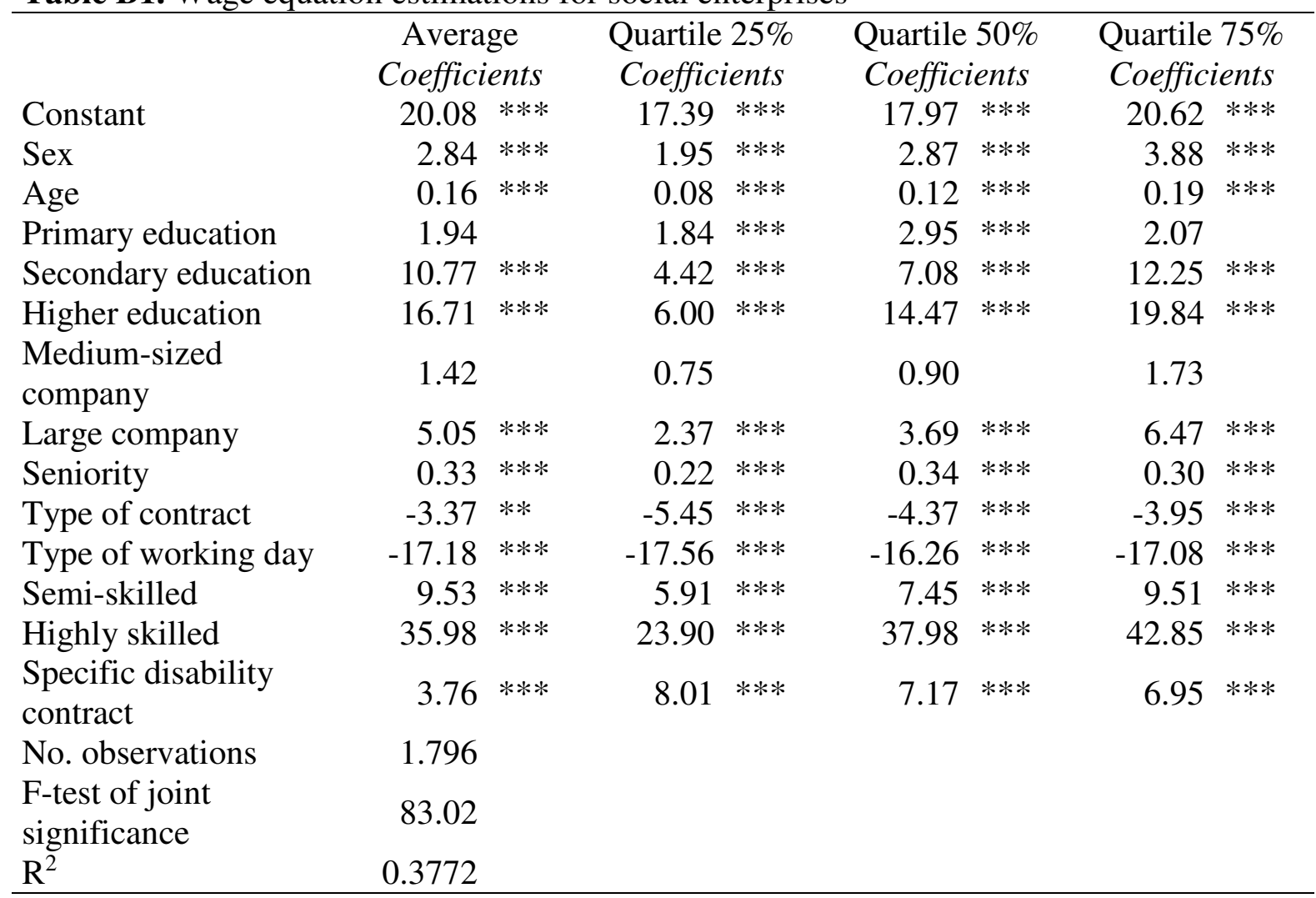

Source: Compiled by the authors from CSWL-CDF 2014

Notes: * p-value $>0.1, * *$ p-value $>0.05, * * *$ p-value $>0.01$. Reference: Woman, with no schooling, working full time in a small-sized firm, with an indefinite contract, unskilled and with a non-specific disability contract. Endogenous variable: Daily wages. 
Table B2. Wage equations estimations for capitalist enterprises

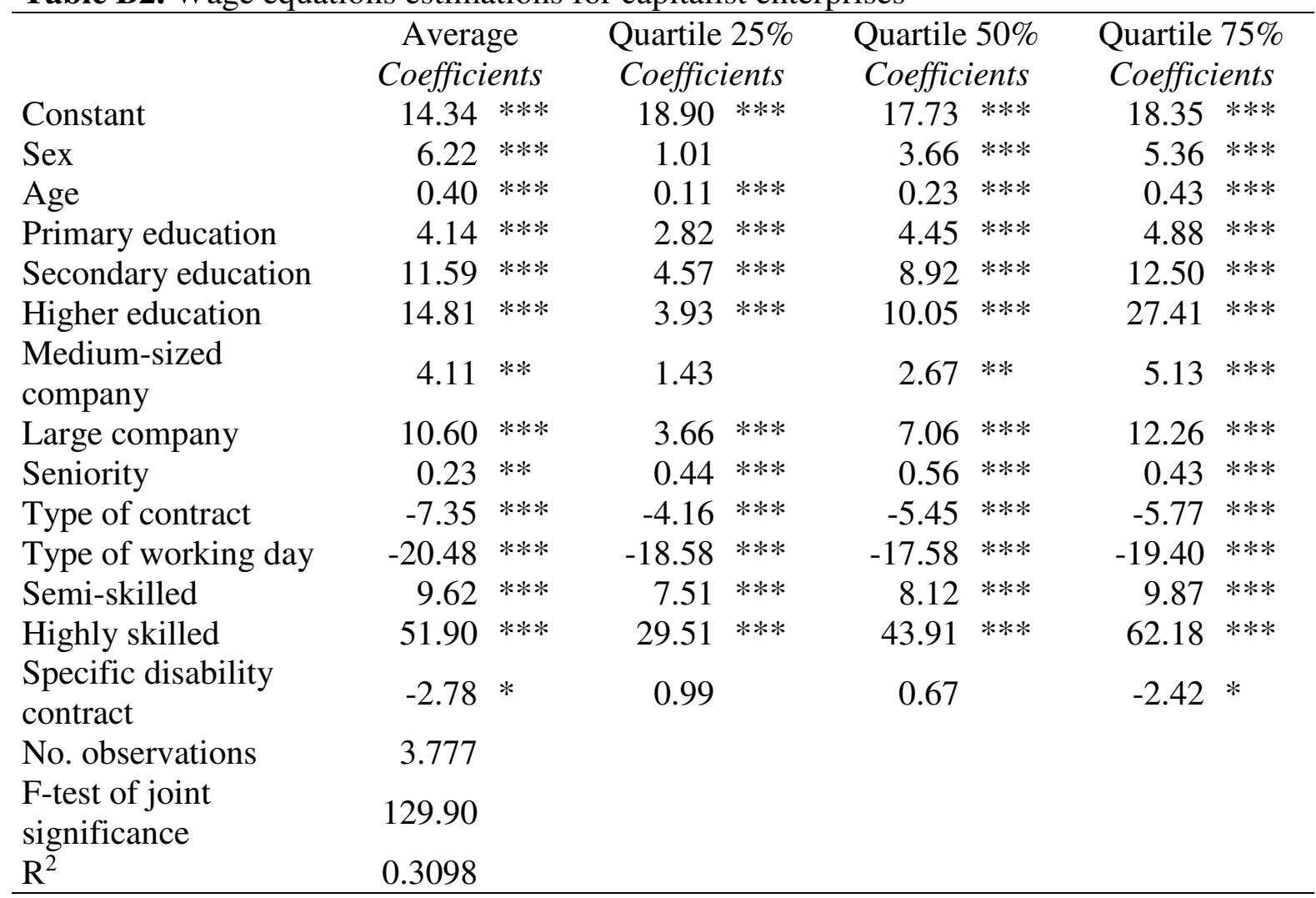

Source: Compiled by the authors from CSWL-CDF 2014

Notes: * p-valor $>0.1, * *$ p-valor $>0.05, * * *$ p-valor $>0.01$. Reference: Woman, with no schooling, working full-time in a small-sized firm, with an indefinite contract, unskilled and with a non-specific disability contract. Endogenous variable: Daily wages. 
Figures

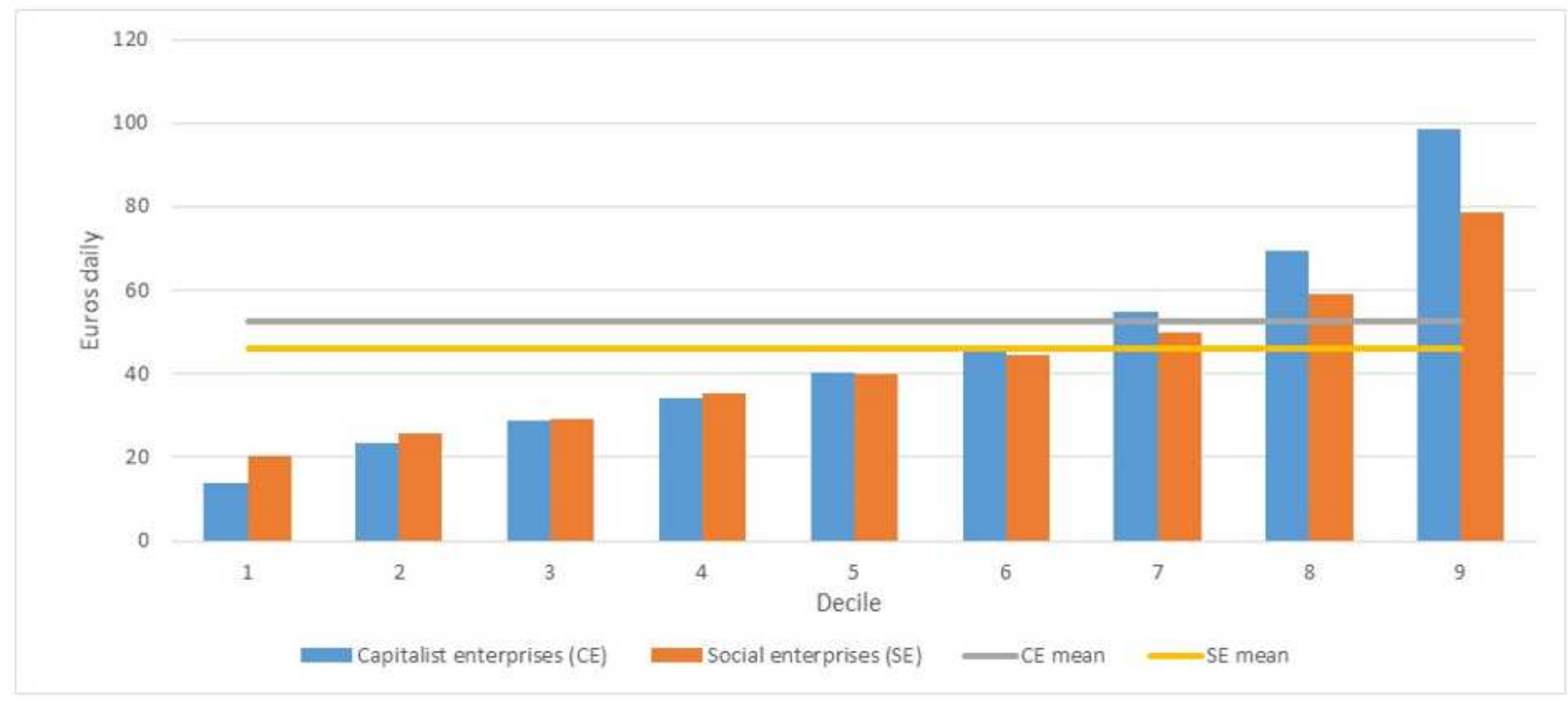

\section{Figure 1}

Decile income distribution for persons with disabilities in social and capitalist enterprises (CSWL-CDF 2014) 